\title{
ARTICLE \\ Sustainability in Higher Education Institutions (HEI): Merging the Study Systematic Review, Analysis Content and Bibliometrics
}

\author{
Érika Pena Bedin* Luiz Carlos de Faria \\ Department of Environmental Sciences, Federal University of São Carlos, Sorocaba, SP, CEP 18052-780, Brazil
}

\section{ARTICLE INFO}

Article history

Received: 2 September2021

Accepted: 26 September 2021

Published Online: 30 September 2021

Keywords:

Sustainability

Systematic and bibliometrics review

Content analysis

Higher education institutions (HEI)

\begin{abstract}
This study aims to explore how the topic of sustainability in Higher Education Institutions (HEI) has been addressed in the scientific literature. It presents a systematic literature review of peer-reviewed journal articles published between 1975 and 2019. After that, bibliometric and content analyses were performed in order to identify the behavior and evolution of the literature and identify the frequency with which they appear in the text, making it possible to raise replicable and valid inferences to the data. The results of this study indicate that the theme is emerging since the year 2010 and with a strong focus on qualitative studies, focused on critical theory. The results indicate that although studies involve the tripod environment, economy, and society, there is still a gap in studies that deal with specific issues to solve practical problems and that analyze the impacts from a more holistic perspective. The combination of methods made it possible to identify and interpret the articles in the selected sample, but based on results reported by other authors, with little room for quality control and integrity.
\end{abstract}

sustainable societies.

In Brazil, sustainability has also been an important topic of political, institutional and scientific order. The first publications on sustainability in journals are in the late 1980s and early 1990s, during which were published major books and international reports ${ }^{[1,2]}$, among Brazilian authors stand out Maimon ${ }^{[3-5]}$, Donaire ${ }^{[6]}$ and Barbieri ${ }^{[7]}$.

It is observed then that deal with sustainability, is not restricted to private organizations, but notes that it is civil society, private organizations and public authorities complement the implementation and promotion of sustainability ${ }^{[8]}$. The government agent plays an important role, either in the preparation, implementation or dissemination

*Corresponding Author:

Érika Pena Bedin,

Department of Environmental Sciences, Federal University of São Carlos, Sorocaba, SP, CEP 18052-780, Brazil;

Email:erika@ufscar.br 
of actions that allow the effective sustainable development. It is the governmental entity, providing means for achieving such sustainability. Therefore, the appropriateness of the public bodies and entities structures is fundamental for the construction of a new institutional culture that includes sustainability as a core principle.

The choice of study in Higher Education Institutions (HEI) is due to the fact of its importance as an example to society through the development of studies and projects that prioritize actions and sustainable practices. Through policies and management practices, the IES have responsibility and should promote sustainable development in the communities in which they operate, influencing the present and the future of every reality ${ }^{[9]}$.

Several studies have been conducted on sustainability in IES. Noeke ${ }^{[10]}$ researched the environmental management system of a university in Germany. Herremans and Allwright ${ }^{[1]]}$ studied sustainability initiatives in American universities. Carpenter and Meehan ${ }^{[12]}$ investigated the environmental management in universities in Australia and New Zealand. Sammalisto and Arvidsson ${ }^{[13]}$ analyzed the implementation of environmental management in Swedish universities. Already Arvidsson ${ }^{[9]}$ investigated the sustainability reports of the Swedish universities, which have a legal obligation to submit such reports.

In this context, this study aims to explore how the theme of sustainability in HEI has been addressed in the scientific literature. Due to the scope extended and diversified its potential application, this research aims to identify articles published with relevance and scope in both themes and analyze the main types, methodologies, scales, dimensions and approaches, as well as trends and gaps.

\section{Materials and Methods}

The combination of systematic literature review and analysis and bibliometric content gives this study qualitative and quantitative characteristic. The systematic review provides the investigation of similarities and differences ${ }^{[14]}$. In turn, the bibliometric analysis is the literature of the behavior of identification and its evolution. Already the content analysis uses mathematical and statistical methods in order to interpret the results ${ }^{[15]}$.

A systematic review from the collection, identification and selection of relevant studies was performed. Thus, the evidence has been mapped; grouped and summarized data and results and identified gaps in the research.

The bibliometric analysis is the literature of the behavior of identification and their evolution in a context and time determined ${ }^{[15]}$. In all the literature, there are significant inconsistencies in how the terms are defined. For example, an author considers a criterion, one can treat as an indicator.

In this study the sustainability information applied in IES were registered in IBM SPSS in order to expose the bibliometric indicators of the selected articles in the literature systematic review and present the results of the analysis in tables and figures.

Content analysis includes descriptive statistics of articles, periodicals, authors and quotes, as well as the analysis of the temporal evolution ${ }^{[14]}$. After the fonts have been selected for inclusion in the study by the systematic literature review and bibliometric analysis. Each source has been read in full for the content analysis. The content was classified according to five characteristics: type, methodology, scale, size and approach.

Finally, data were extrapolated and interpreted after cross-examination of the characteristics of the dimensions of sustainability.

\section{Results and Discussion}

Initially will be presented the results of a systematic literature review in order to obtain an overview of the publications. Following, we will discuss the results of bibliometric analysis and content of the articles, in order to detail the characteristics of this group of publications.

\subsection{Systematic Review of Literature}

The starting point has been established by the following question: which path characteristics of HEI research on the scientific production in the area of sustainability? To address this issue, a systematic review followed the process illustrated in Figure 1.

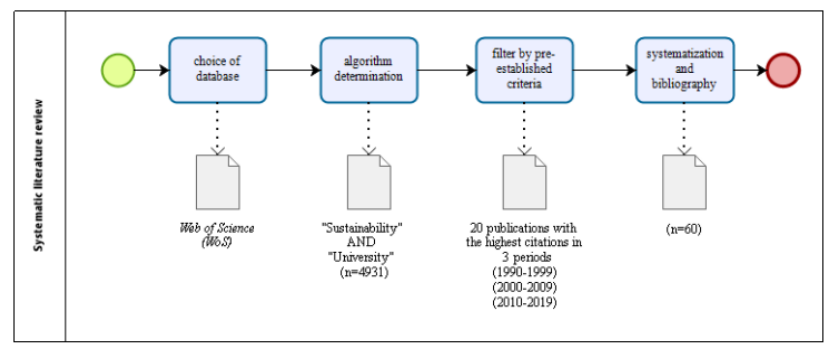

Figure 1. Implementing process of systematic review of the literature

The documents for this review were identified from the database Web of Science (WoS). This database provides comprehensive coverage of subjects considered relevant, as well as access to bibliographic data for further elaboration of tables and graphs.

The search terms were identified and refined even further selection criteria by reviewing a sample of random publications of the search results. A comprehensive survey was completed in November 2019 using the ultimate 
combination of search terms, "Sustainability" AND "University".

Regarding the time period it was decided to no restriction in order to ensure a greater range of bibliometric analysis. Therefore, the study was conducted between 1975 and 2019.

The initial search in the database resulted in a total of 4,931 publications, geographically distributed as shown in Figure 2.

Figure 2 shows that the theme recurs in the international literature, countries like the United States of America (649 items) and the UK (388 articles) are the highest number of publications, followed by Australia (257 articles) and Spain (148 articles). Shortly thereafter are Canada (126 products), Germany (114 products), Malaysia (100 products), Brazil (98 items), and China (90 items). Following is South Africa (81 items), the Netherlands (78), Portugal (77 articles), Sweden (71 articles), Italy (65 articles) and Mexico (40 articles). The sum of items of other countries represent $18.08 \%$ of the total.

In a temporal analysis of the articles could be identified that 4,931 articles identified in the initial portfolio represents 28 years of research with an emphasis on sustainability in the IES on the basis WoS, and have average annual publication of 63 articles.

Figure 3 illustrates the distribution of publications (column) and citations (stacked area) each year. Observed the growing number of publications and citations received. Please note that the number of citations corresponds to the indications received under the Main WoS collection.

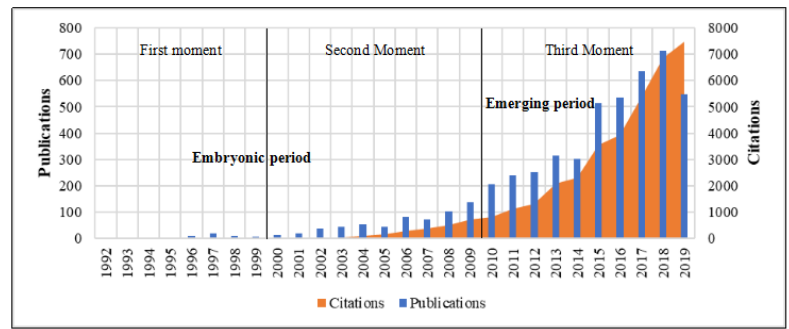

Figure 3. Evolution of publications and citations wos between 1990 and 2019 (blunt criterion)

In terms of publications and citations were identified statically three stages of study: from 1990 to 1999 as the first, from 2000 to 2009 as the second time, and from 2010 to 2019 as the third time (Table 1).

Table 1. Descriptive statistics: percentiles

\begin{tabular}{|c|c|c|c|c|}
\hline \multicolumn{2}{|c|}{} & Year & Publications & quotes \\
\hline \multirow{2}{*}{ percentiles } & 33.33333333 & 1999 & 16 & 27 \\
\cline { 2 - 5 } & 66.66666667 & 2009 & 183 & 782 \\
\hline
\end{tabular}

In addition, it was detected the first and second times, such as embryonic, as they represent only 16 publications and 27 quotations. The third time was identified as an emerging period, since it represents 183 publications and 782 citations.

The first embryonic marks the beginning of publications on the theme. At first, between 1990 and 1999 were recorded articles 62 and 75 quotes, which together represent $1.26 \%$ and $0.20 \%$ of publications and citations,

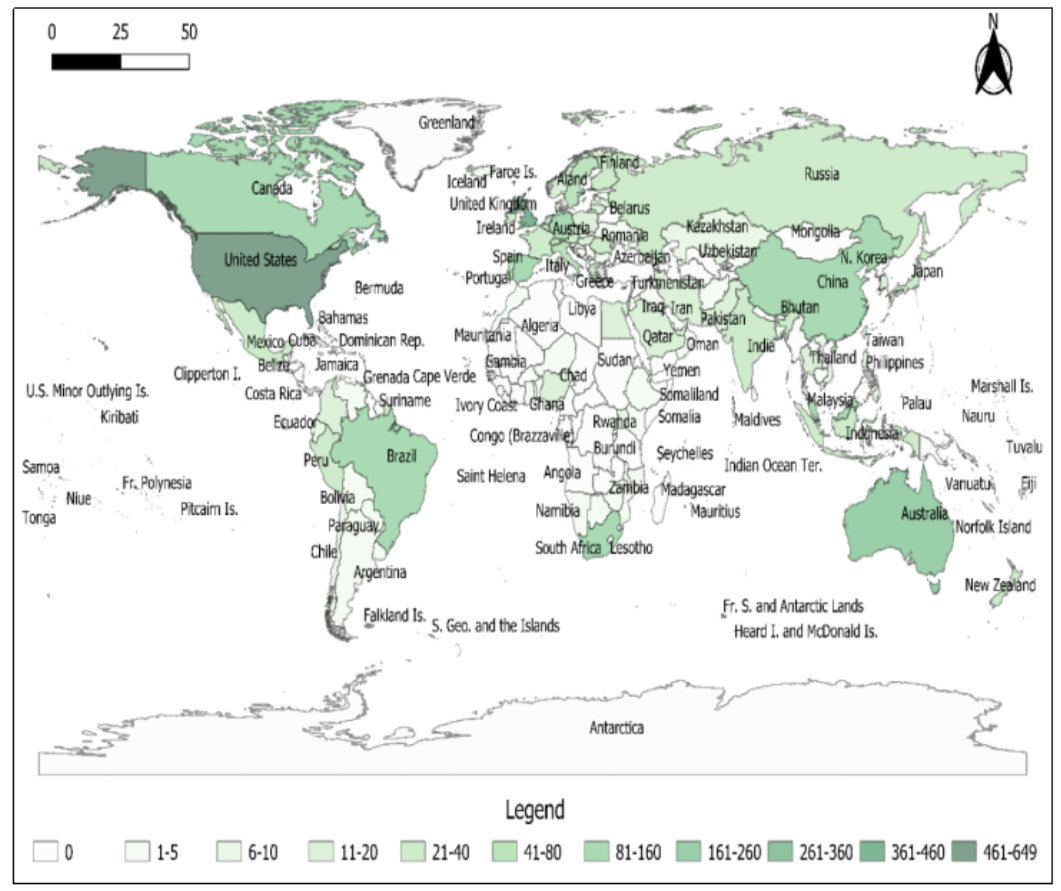

Figure 2. Geographical distribution of the published documents 
respectively. The dissemination of publications, the ratio between the average citations and the average is 1.21 publications, as can be seen in the early years of the series.

In the second phase it is observed a small increase in the number of articles and quotations, especially from the 2000 s, which concentrates $12.31 \%$ of all published articles. The number of citations is significant representing $6.22 \%$ of the total received mentions. The increase in the number of citations is observed from the increase of the ratio between the average and the average of citations to publications reaches 3.81 , which represents a 3.15 fold increase in the order from the previous decade.

The third time is considered an emerging period due to the growth rate of publications: $87.69 \%$ and the quote: $93.78 \%$ from 2010. In this respect, the period 2010 to 2019 concentrates $86.43 \%$ of the articles published and $93.58 \%$ of incoming quotes. It is observed that, during this period, the ratio between quote and publications increased to 8.19 , showing an increase of spread within the WoS, publications analyzed and hence the expansion of themes in the area.

From the survey of 4,931 items, which form the initial portfolio, the most cited articles were identified under the WoS. Figure 4 shows the items 1166 received at least seven quotes, representing $23.99 \%$ of the total document.

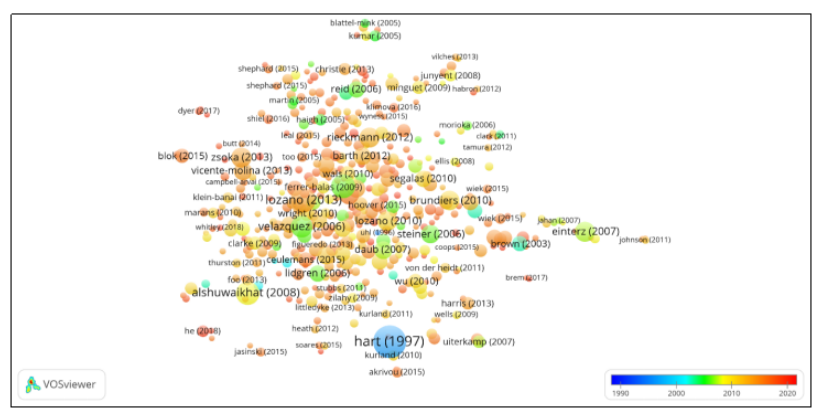

Figure 4. Sample Mapping articles with cutting criterion 7 citations for publications

The colors of the circles indicate the year of publication, as the caption displayed in the lower right corner. But the size reflects the number of citations received. The choice of criteria seven underlies It quotes the observation that the 90 shows the annual average of 7 quotes. Thus, it sought to incorporate the figure this period, despite representing only $0.21 \%$ of total citations, is relevant because it is the period when the research began.

Among the articles published in 1990, identified by blue color (Figure 4), stands out as the most cited work of Hart ${ }^{[16]}$ entitled Beyond greening: Strategies for the sustainable world. The article published in the Harvard Business Review received 593 citations and has annual average of citations equal to 21.18 , while the research
Uhl, Kulakowski, Gerwing, Brown and Cochrane ${ }^{[17]}$ received only 8 quotes.

The period between 2000 and 2009, shown in Figure 4 with colors ranging from pale blue to yellow, focuses items with intermediate quotes. The article published by Lozano ${ }^{[18]}$, entitled incorporation and institutionalization of SD into universities: breaking through barriers to change has 264 citations and average annual equal citations 9.43 . Further, there is the study published in 2008 by Alshuwaikhat and Abubakar ${ }^{[19]}$ with 247 citations and average annual equal citations 8.82. In sequence is the Daub ${ }^{[20]}$, which has 130 citations and average annual equal citations 4.64.

But the most recent period spanning between 2010 and 2019, shown in Figure 4 with colors ranging from light to red orange, concentrates the most quoted items analyzed together. The article Lozano ${ }^{[21]}$ titled Declarations for sustainability in higher education: Becoming better leaders, through addressing the university system, has 281 citations and average of 10.04 citations, and is the most cited of all the analyzed publications. Soon after, another appears Lozano ${ }^{[22]}$, which has 161 citations and annual average of 5.75 citations.

The analysis revealed that the periodic 4,931 selected articles were published in 1633 in the journal indexed WoS, as shown in Figure 5.

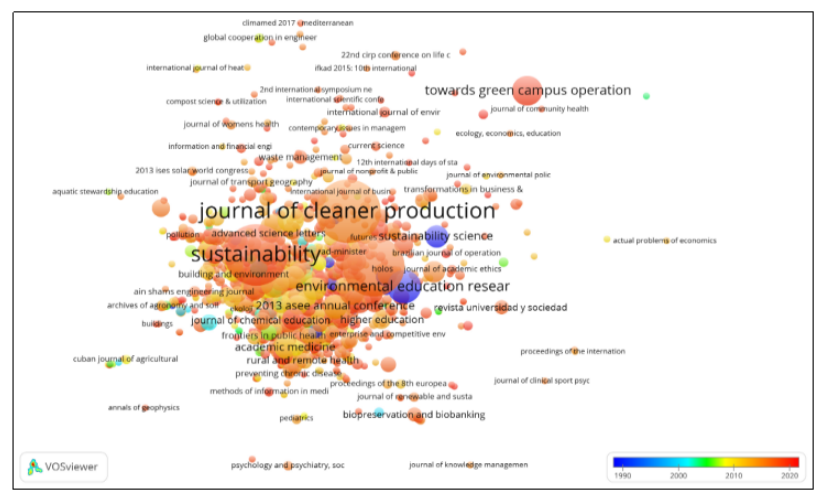

Figure 5. Mapping of journals where the articles were published initial sample

The colors of the circles indicate the average year of publication, as legend displayed in the lower right corner of the figure. But the size reflects the number of published articles.

In the initial period (1990), two journals stand out regarding the number of items, although they have not previously dominated the period studied. The Environmental Education Research presented articles 50 (1.03\%) is released in the UK, and is indexed in WoS since 2000. The second most productive journal, in the 1990s, it is the Sustainability Science articles 19 showed that $(0,39 \%)$, is 
published in Germany, and is indexed in WoS since 2007.

In the $2000 \mathrm{~s}$, the most prominent journal in terms of number of publications, is the Water Science and Technology with 9 articles $(0.19 \%)$. The journal, which is published in Germany, and indexed since 2013.

More recently, between 2010 and 2019, include: Journal of Cleaner Production indexed since 1993, has 263 articles (5.41\%); Sustainability the Periodic indexed since 2009, with 242 articles (4.98\%); and International Journal of Sustainability in Higher Education, indexed since 2000, and rely on articles 234 (4.81\%).

Figure 6 shows the affiliation of the authors institutions, totaling 391 organizations, including universities and research organizations.

It is observed in Figure 6, the predominance with 1,212 citations, publications of authors linked to the Arizona State University (United States). Between 2000 and 2010, the highlights are the authors of the MIT University (United States) with 338 citations and State of Saint Paul (Brazil) with 309 citations. As of 2010, there is the University of Michigan (United States) with 325 citations.

After mapping the original sample $(n=4.931)$, the items have been grouped into three periods (Table 2), according to three previously identified times: 1990 to 1999 , 2000 to 2009 and 2010 to 2019.

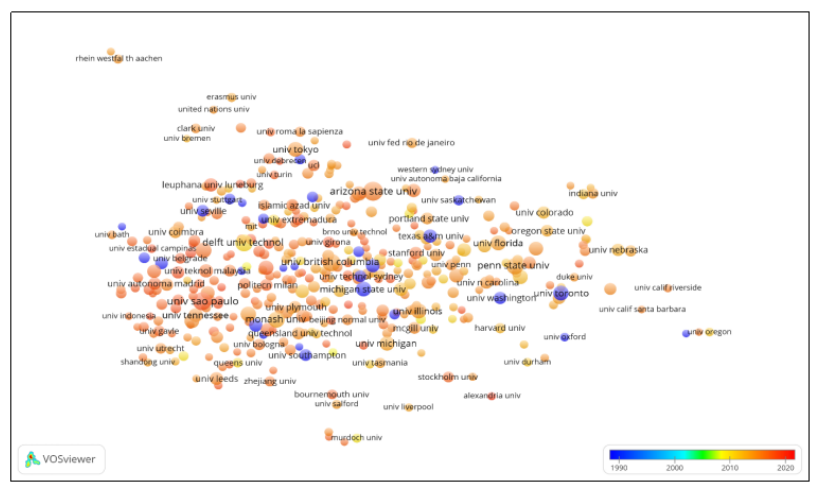

Figure 6. Membership institutions of the authors of articles

In the evaluation phase, the criterion used in the selection of publications is based on the average of quotations, and selected the twenty publications with annual average citations $(n=20)$ of each period. A citation analysis of the premise that the authors cite more works that are important in the development of their research.

The oldest publication is dated 1992 and the latest in 2015. To facilitate the analyzes were assigned codes (ID) to each of the selected items, which are presented in the first column.

One of the criteria adopted for selection of studies is access to the full text. Another criterion used was the service to the theme sustainability in HEI, considering the objective of this study. The results of this step are shown in Table 3.

Table 3. Description of the categories adopted for selection of studies

\begin{tabular}{|c|c|c|c|}
\hline Period & $\begin{array}{c}\text { Total analyzed } \\
\text { publications }\end{array}$ & $\begin{array}{c}\text { Complete } \\
\text { text }\end{array}$ & $\begin{array}{c}\text { Sustainability in } \\
\text { IES }\end{array}$ \\
\hline $1990-1999$ & 20 & 18 & 3 \\
\hline $2000-2009$ & 20 & 20 & 5 \\
\hline $2010-2019$ & 20 & 20 & 12 \\
\hline totals & $\mathbf{6 0}$ & $\mathbf{5 8}$ & $\mathbf{2 0}$ \\
\hline
\end{tabular}

Articles were excluded if they had not in full text the term "Sustainability" AND "University" OR "Higher Education", considering the title, abstract or keywords.

Of the 60 articles selected initially, 40 were excluded for not meeting the established criteria. Among the items removed two did not have the full text. publications were also found that addressed sustainability, but they were not related to the HEI context. As a result, we selected 20 articles for a systematic review of the literature.

\subsection{Analysis Bibliometric}

In this study, shown in Figure 7, the analysis bibliometric exposes bibliometric indicators of selected articles in a systematic literature review: title, author (s), periodic, year, and average citation reference. Moreover, it presents the results of analysis by the table and figures.

Table 2. Total of publications and citations for the period analyzed

\begin{tabular}{|c|c|c|c|c|c|c|}
\hline Period & $\begin{array}{c}\text { Total period of } \\
\text { publications }\end{array}$ & $\begin{array}{c}\text { Total period of } \\
\text { quote (A) }\end{array}$ & $\begin{array}{c}\text { Total citations } \\
\mathbf{( N = 2 0 )}(\mathbf{B})\end{array}$ & $\begin{array}{c}\text { Quotes } \\
\mathbf{( B ~ / ~ A ) ~}\end{array}$ & $\begin{array}{c}\text { Average annual } \\
\text { period quotes }\end{array}$ & $\begin{array}{c}\text { Average annual } \\
\text { quotes } \\
(\mathbf{N}=\mathbf{2 0})\end{array}$ \\
\hline $1990-1999$ & 62 & 1410 & 1322 & $93.76 \%$ & 1.87 & 2.82 \\
\hline $2000-2009$ & 607 & 11,224 & 3857 & $34.36 \%$ & 1.78 & 13.15 \\
\hline $2010-2019$ & 4,262 & 24,768 & 3038 & $12.27 \%$ & 1.17 & 20.05 \\
\hline
\end{tabular}


Table 4. Selected Items for bibliometric analysis

\begin{tabular}{|c|c|c|c|c|c|c|c|}
\hline ID & Title & Author (s) & Filiation & Journal & Year & Citation & Average \\
\hline \multicolumn{8}{|c|}{ 1st Period (1990-1999) } \\
\hline 11 & $\begin{array}{l}\text { Beyond greening: Strategies } \\
\text { for the sustainable world }\end{array}$ & Hart, SL & U.S & $\begin{array}{l}\text { Harvard Business } \\
\text { Review }\end{array}$ & 1997 & 601 & 26.13 \\
\hline 17 & $\begin{array}{c}\text { Sustainable development and } \\
\text { technology assessment }\end{array}$ & Jischa, MF & Germany & $\begin{array}{c}\text { Chemical Engineering } \\
\& \text { Technology }\end{array}$ & 1998 & 10 & 0.45 \\
\hline 18 & $\begin{array}{c}\text { Issues of sustainability and } \\
\text { pollution prevention in } \\
\text { environmental engineering } \\
\text { education } \\
\end{array}$ & $\begin{array}{l}\text { Gutierrez-Martin, F; } \\
\text { Dahab MF }\end{array}$ & Spain & $\begin{array}{l}\text { Water Science and } \\
\text { Technology }\end{array}$ & 1998 & 8 & 0.36 \\
\hline \multicolumn{8}{|c|}{ 2nd Period (2000-2009) } \\
\hline 28 & $\begin{array}{c}\text { Incorporation and } \\
\text { institutionalization of SD into } \\
\text { universities: breaking through } \\
\text { barriers to change }\end{array}$ & Lozano, R & UK & $\begin{array}{l}\text { Journal of Cleaner } \\
\text { Production }\end{array}$ & 2006 & 267 & 19.07 \\
\hline 30 & $\begin{array}{l}\text { Sustainable university: what } \\
\text { can be the matter? }\end{array}$ & \begin{tabular}{|c|} 
Velazquez, L; Munguia, \\
N; Platt, A; Taddei, J \\
\end{tabular} & Mexico & $\begin{array}{c}\text { Journal of Cleaner } \\
\text { Production }\end{array}$ & 2006 & 212 & 15.14 \\
\hline 31 & $\begin{array}{c}\text { Higher education for } \\
\text { sustainability by means of } \\
\text { transdisciplinary case studies: } \\
\text { an innovative approach for } \\
\text { solving complex, real-world } \\
\text { problems } \\
\end{array}$ & Steiner L; Posch, A & Austria & $\begin{array}{l}\text { Journal of Cleaner } \\
\text { Production }\end{array}$ & 2006 & 137 & 9.79 \\
\hline 34 & $\begin{array}{c}\text { The systemic approach to } \\
\text { incorporate sustainability } \\
\text { into university courses and } \\
\text { curricula }\end{array}$ & $\begin{array}{l}\text { Lidgren, A; Rodhe H; } \\
\text { Huisingh, D }\end{array}$ & Sweden & $\begin{array}{l}\text { Journal of Cleaner } \\
\text { Production }\end{array}$ & 2006 & 102 & 7.29 \\
\hline 40 & $\begin{array}{c}\text { An integrated approach to } \\
\text { sustainability Achieving } \\
\text { campus: assessment of the } \\
\text { current campus environmental } \\
\text { management practices }\end{array}$ & $\begin{array}{c}\text { Alshuwaikhat HM.; } \\
\text { Abubakar I }\end{array}$ & Saudi Arabia & $\begin{array}{c}\text { Journal of Cleaner } \\
\text { Production }\end{array}$ & 2008 & 262 & 21.83 \\
\hline \multicolumn{8}{|c|}{$3 r d$ Period (2010-2019) } \\
\hline 41 & $\begin{array}{c}\text { Real-world learning } \\
\text { opportunities in sustainability: } \\
\text { from classroom into the real } \\
\text { world }\end{array}$ & $\begin{array}{l}\text { Brundiers, K; Wiek, A; } \\
\text { Redman, CL }\end{array}$ & U.S & $\begin{array}{c}\text { International Journal } \\
\text { of Higher Education } \\
\text { in Sustainability }\end{array}$ & 2010 & 167 & 16.7 \\
\hline 42 & $\begin{array}{c}\text { Diffusion of sustainable } \\
\text { development in universities' } \\
\text { curricula: an empirical } \\
\text { example from Cardiff } \\
\text { University }\end{array}$ & Lozano, R & UK & $\begin{array}{l}\text { Journal of Cleaner } \\
\text { Production }\end{array}$ & 2010 & 161 & 16.1 \\
\hline 47 & $\begin{array}{l}\text { The state of sustainability } \\
\text { reporting in universities }\end{array}$ & Lozano, R & UK & \begin{tabular}{|c|}
$\begin{array}{c}\text { International Journal } \\
\text { of Higher Education } \\
\text { in Sustainability }\end{array}$ \\
\end{tabular} & 2011 & 118 & 13.11 \\
\hline 48 & $\begin{array}{l}\text { Future-oriented higher } \\
\text { education: Which key } \\
\text { competencies shouldnt be } \\
\text { fostered through university } \\
\text { teaching and learning? }\end{array}$ & Rieckmann, M & Germany & Futures & 2012 & 185 & 23.13 \\
\hline 49 & $\begin{array}{l}\text { Academic staff development } \\
\text { as a catalyst for curriculum } \\
\text { change towards education for } \\
\text { sustainable development: an } \\
\text { output perspective }\end{array}$ & Barth, F; Rieckmann, M & Australia & $\begin{array}{l}\text { Journal of Cleaner } \\
\text { Production }\end{array}$ & 2012 & 116 & 14.5 \\
\hline
\end{tabular}


Macro Management \& Public Policies | Volume 03 | Issue 03 | September 2021

\begin{tabular}{|c|c|c|c|c|c|c|c|}
\hline 50 & \begin{tabular}{|c|} 
Environmental Management \\
Systems (EMS) \\
implementation processes \\
and practices in European \\
higher education institutions - \\
Top-down approaches versus \\
participatory \\
\end{tabular} & $\begin{array}{c}\text { Disterheft, A; Ferreira da } \\
\text { Silva Caeiro, SS; Ramos, } \\
\text { MR; Miranda Azeiteiro, } \\
\text { A }\end{array}$ & Portugal & $\begin{array}{l}\text { Journal of Cleaner } \\
\text { Production }\end{array}$ & 2012 & 102 & 12.75 \\
\hline 51 & $\begin{array}{c}\text { Declarations for sustainability } \\
\text { in higher education: } \\
\text { Becoming better leaders, } \\
\text { through addressing the } \\
\text { university system }\end{array}$ & $\begin{array}{c}\text { Lozano, R; Lukman, R; } \\
\text { Lozano, FJ.; Huisingh, D; } \\
\text { Lambrechts, W }\end{array}$ & Slovenia & $\begin{array}{l}\text { Journal of Cleaner } \\
\text { Production }\end{array}$ & 2013 & 284 & 40.57 \\
\hline 53 & \begin{tabular}{|c|} 
Greening due to \\
environmental education? \\
Environmental knowledge, \\
attitudes, behavior and \\
consumer pro-environmental \\
activities of everyday \\
Hungarian high school and \\
university students
\end{tabular} & $\begin{array}{c}\text { Zsoka, A; Szerenyi ZM; } \\
\text { Szechy, A; Kocsis, T }\end{array}$ & Hungary & $\begin{array}{l}\text { Journal of Cleaner } \\
\text { Production }\end{array}$ & 2013 & 169 & 24.14 \\
\hline 54 & $\begin{array}{c}\text { Environmental knowledge } \\
\text { and other variables Affecting } \\
\text { pro-environmental behavior: } \\
\text { comparison of university } \\
\text { students from emerging and } \\
\text { advanced countries } \\
\end{array}$ & $\begin{array}{c}\text { Azucena Vicente-Molina } \\
\text { M; Fernandez-Sainz, A; } \\
\text { Izagirre-Olaizola, J }\end{array}$ & Spain & $\begin{array}{l}\text { Journal of Cleaner } \\
\text { Production }\end{array}$ & 2013 & 133 & 19 \\
\hline 55 & $\begin{array}{c}\text { An in-depth review of the } \\
\text { literature and roles evolving } \\
\text { contributions of universities } \\
\text { to Education for Sustainable } \\
\text { Development }\end{array}$ & Karatzoglou, B & Greece & $\begin{array}{l}\text { Journal of Cleaner } \\
\text { Production }\end{array}$ & 2013 & 131 & 18.71 \\
\hline 58 & $\begin{array}{c}\text { Advancing Higher Education } \\
\text { for Sustainable Development: } \\
\text { International critical } \\
\text { reflections and insights } \\
\end{array}$ & $\begin{array}{c}\text { Lozano, R; Lozano, FJ; } \\
\text { Mulder, K; Huisingh, D; } \\
\text { Waas, T }\end{array}$ & Netherlands & $\begin{array}{c}\text { Journal of Cleaner } \\
\text { Production }\end{array}$ & 2013 & 104 & 14.86 \\
\hline 60 & $\begin{array}{c}\text { The review of commitment } \\
\text { and implementation of } \\
\text { sustainable development in } \\
\text { higher education: results from } \\
\text { a survey worldwide }\end{array}$ & \begin{tabular}{|c|} 
Lozano, R; Ceulemans, \\
K; Alonso-Almeida M; \\
Huisingh, D; Lozano, FJ; \\
Waas, T; Lambrechts, W; \\
Lukman, R; Huge, J \\
\end{tabular} & Netherlands & $\begin{array}{c}\text { Journal of Cleaner } \\
\text { Production }\end{array}$ & 2015 & 164 & 32.8 \\
\hline
\end{tabular}

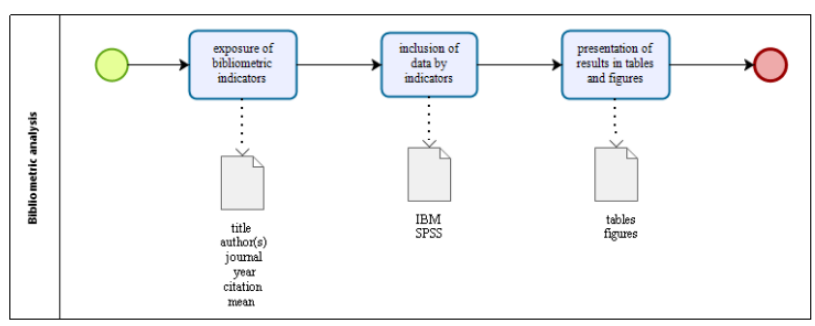

Figure 7. Implementing process of bibliometric analysis

The 20 items selected as a sample for analysis bibliometric are shown in Table 4.

When we analyzed the authors of the publications, one realizes that only Lozano R. published articles 6 of 20 of the sample. Thus, it is evident an open field for other research and researchers the sustainability issue in HEI.
The geographical origin of affiliation of the authors who have published articles, as Figure 8 shows a distribution around the world, however, with the largest representation in Europe (15): Austria (1), Germany (2), Greece (1), Hungary (1), Netherlands (2), Portugal (1), Spain (2), Slovenia (1), Sweden (1), United Kingdom (3); followed by North America (3): United States (2), Mexico (1); Asia (1): Saudi Arabia (1) and Oceania (1): Australia (1). Note that no work originated in Latin America and Africa.

As shown in Figure 9, the sample articles come from a variety of different periodic 6 , with the greatest presence of the Journal of Cleaner Production $70 \%$ of posts (14, 20). Something interesting is that this journal focuses on transdisciplinary research involving Cleaner Production, Environmental and Sustainability. 


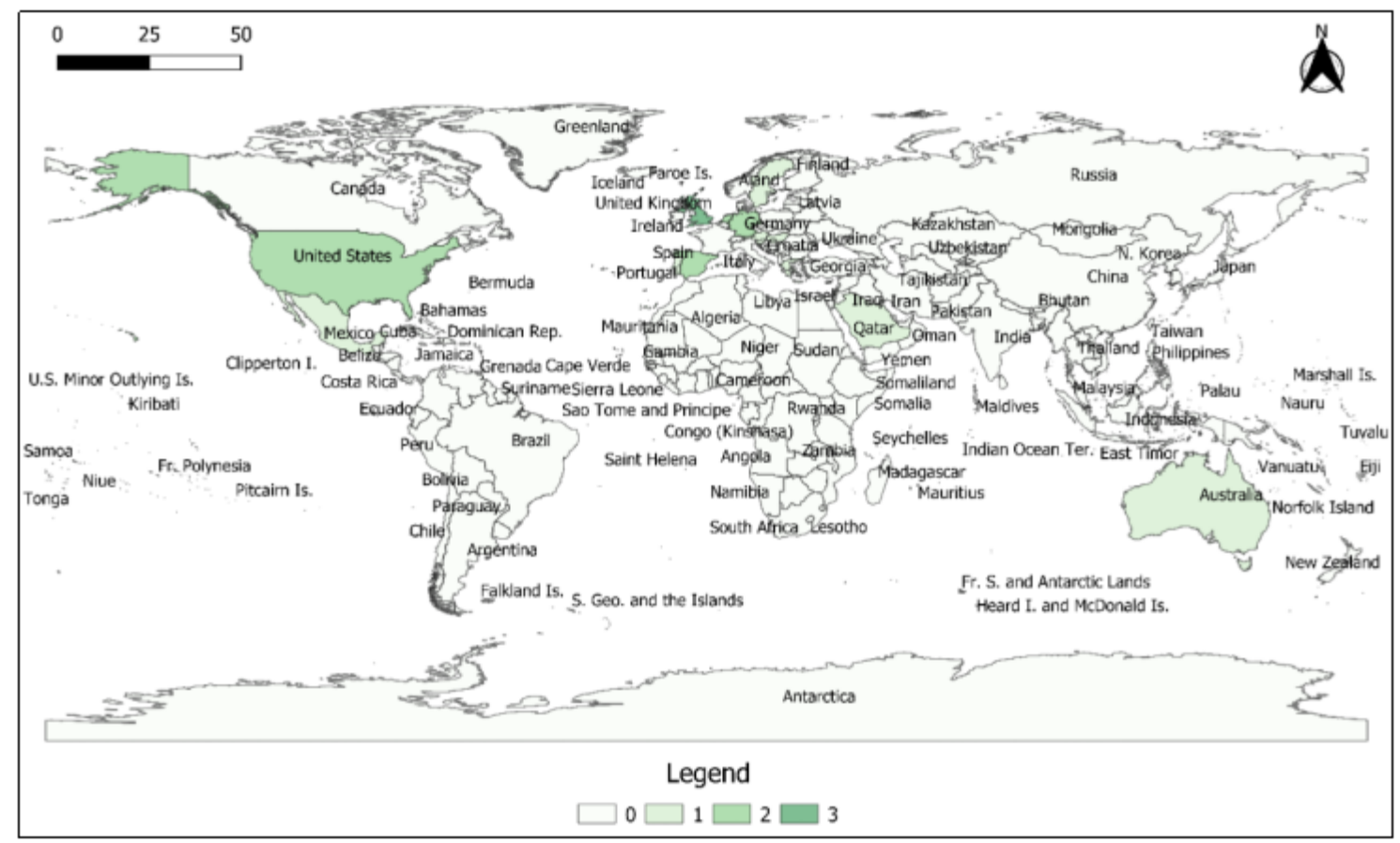

Figure 8. Distribution of articles selected by geographic origin

\begin{tabular}{|lr|l|}
\hline Journal of Cleaner Production & 14 & \\
International Journal of Sustainability in Higher Education & 2 & $10 \%$ \\
Harvard Business Review & 1 & $5 \%$ \\
Chemical Engineering \& Technology & 1 & $5 \%$ \\
Water Science and Technology & 1 & $5 \%$ \\
Futures & 1 & $5 \%$ \\
Total & $\mathbf{2 0}$ & \\
\hline
\end{tabular}

Figure 9. Distribution of publications in relation to periodic

The temporal distribution of items (Figure 10) indicates recent occurring theme in the literature, since only three articles published received higher quotes by 2005 . In 2006, there was a first peak of publications, signaling the emergence of developing studies on the subject and, the year 2013 stands out with $25 \%$ of articles published in more citations. Worth noting also the fact that since 2015 was the last year with articles that received the highest quotes.

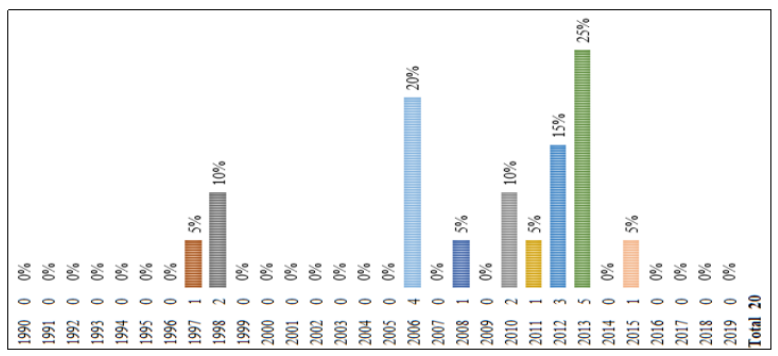

Figure 10. Monthly distribution of publications

Figure 11 illustrates the distribution of quotes (column) and average quotes (line) of each item classified by the ID number. It is observed that the article identified by the
ID 11 alone received the highest number of citations. This indicates that such an article has been considered as a reference of the studied subject.

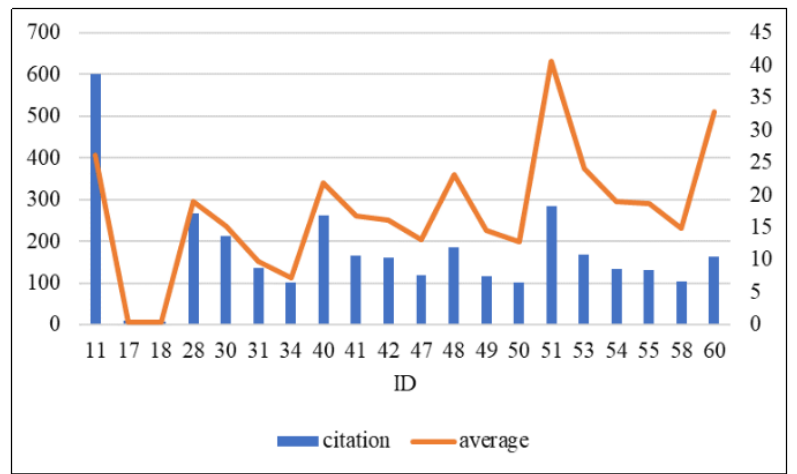

Figure 11. Distribution of citations and medium

\subsection{Content Analysis}

The content analysis was performed in three stages: pre-analysis, exploration of material and processing results (Figure 12).

After completion of reading, the selected studies were classified according to five characteristics: type (qualitative, quantitative and qualitative / quantitative) methodology (case study, theoretical / conceptual and modeling), scale (local and global), dimension (environmental / economic / social, environmental / economic, environmental / social and environmental) and approach (critical theory and problem solving). 


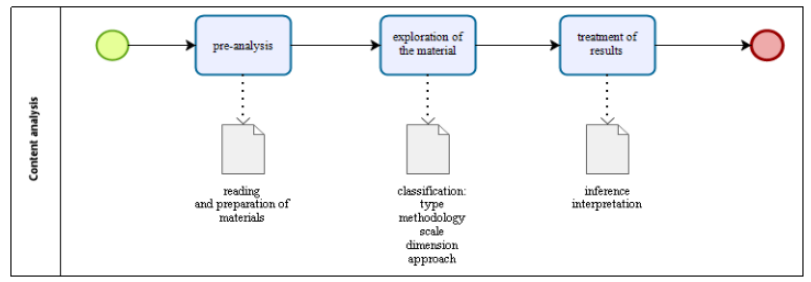

Figure 12. Procedures for the implementation of content analysis

In order to facilitate analysis, data were synthesized according to the analyzed frequency characteristics (Figure 13).

\begin{tabular}{|c|c|c|c|}
\hline Type & $\begin{array}{c}\text { qualitative } \\
\text { quantitative } \\
\text { qualitative/quantitative } \\
\text { total }\end{array}$ & $\begin{array}{c}15 \\
3 \\
2 \\
20\end{array}$ & 75\% $15 \%$ \\
\hline Methodology & $\begin{array}{l}\text { case study } \\
\text { theoretical } / \text { conceptual } \\
\text { modeling } \\
\text { total } \\
\end{array}$ & $\begin{array}{c}7 \\
10 \\
3 \\
20 \\
\end{array}$ & 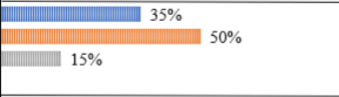 \\
\hline Scale & $\begin{array}{l}\text { local } \\
\text { global } \\
\text { total }\end{array}$ & $\begin{array}{c}6 \\
14 \\
20\end{array}$ & $30 \%$ \\
\hline Dimension & $\begin{array}{l}\text { environmental/economic/social } \\
\text { environmentaleconomic } \\
\text { environmental/social } \\
\text { environmental } \\
\text { total }\end{array}$ & $\begin{array}{c}12 \\
1 \\
5 \\
2 \\
20\end{array}$ & 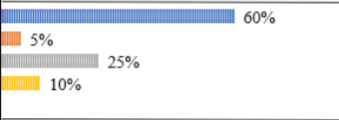 \\
\hline Approach & $\begin{array}{l}\text { critical theory } \\
\text { resolution problems } \\
\text { total }\end{array}$ & $\begin{array}{c}14 \\
6 \\
20\end{array}$ & 70\% \\
\hline
\end{tabular}

Figure 13. Characteristics of selected articles

It can be seen that most of the studies are of qualitative $(75 \%)$, use is made of theoretical / conceptual methodology $(50 \%)$, include global $(70 \%)$ have environmental dimension / economic / social (60\%) and address critical theory $(70 \%)$. After this operation, the data were processed and the inferred results and interpreted in relation to the three dimensions of sustainability: environmental, economic and social.

Making a cross-analysis of the dimensions of sustainability versus types of research used in the sample publications it has been, that the 15 qualitative studies presented $53.3 \%$ have an environmental connotation / economic / social (Table 5).

Another analysis of the dimensions of sustainability versus methodologies used in sample surveys has been that of the 10 studies theoretical / conceptual presented $80 \%$ have an environmental connotation / economic / social (Table 6).

Already analyzing the dimensions of sustainability versus breadth of scale has been that of 14 studies on a global scale presented $64.3 \%$ have an environmental connotation / economic / social (Table 7).

When evaluating the dimensions of sustainability versus approach has been that of the 14 studies in critical theory approach presented $57.1 \%$ have an environmental connotation / economic / social (Table 8).

Performing an analysis of the periodic publications of the sample draws attention the Journal of Cleaner Production, which in addition to having most of the articles shows that $64.3 \%$ of them have a connotation / environmental / economic / social (Table 9).

Finally, cross-temporal analysis of the sample (Table 10) was performed.

This analysis identified the year 2013 as having 5 of the 20 articles of the sample. In addition, $100 \%$ of them have an environmental connotation / economic / social.

\section{Conclusions}

The literature of systematic review and bibliometric and content analysis showed that the topic of sustainability in HEI is an emerging period since 2010.

It can be concluded that most research initiatives are being made by means of theoretical methods / conceptual, analysing the environment tripod, economy and society, but mostly qualitative way, leaving to explore problem solving in order to increase its generalization. It is evident, too, the need for studies on the integration of two themes:

Table 5. Types of research versus dimensions of sustainability

\begin{tabular}{|c|c|c|c|c|c|c|c|c|c|c|}
\hline \multirow{3}{*}{ TYPE } & \multicolumn{10}{|c|}{ DIMENSION } \\
\hline & \multicolumn{2}{|c|}{$\begin{array}{c}\text { environmental/ } \\
\text { economic/ } \\
\text { social }\end{array}$} & \multicolumn{2}{|c|}{$\begin{array}{c}\text { environmental/ } \\
\text { economic }\end{array}$} & \multicolumn{2}{|c|}{$\begin{array}{c}\text { environmental/ } \\
\text { social }\end{array}$} & \multicolumn{2}{|c|}{ environmental } & \multicolumn{2}{|c|}{ total } \\
\hline & $\mathrm{n}$ & $\%$ & $\mathrm{n}$ & $\%$ & $\mathrm{n}$ & $\%$ & $\mathrm{n}$ & $\%$ & $\mathrm{n}$ & $\%$ \\
\hline qualitative & 8 & $53.3 \%$ & 1 & $6.7 \%$ & 4 & $26.7 \%$ & 2 & $13.3 \%$ & 15 & $100.0 \%$ \\
\hline quantitative & 3 & $100.0 \%$ & 0 & $0.0 \%$ & 0 & $0.0 \%$ & 0 & $0.0 \%$ & 3 & $100.0 \%$ \\
\hline qualitative / quantitative & 1 & $50.0 \%$ & 0 & $0.0 \%$ & 1 & $50.0 \%$ & 0 & $0.0 \%$ & 2 & $100.0 \%$ \\
\hline
\end{tabular}


Macro Management \& Public Policies | Volume 03 | Issue 03 | September 2021

Table 6. Methodologies used versus dimensions of sustainability

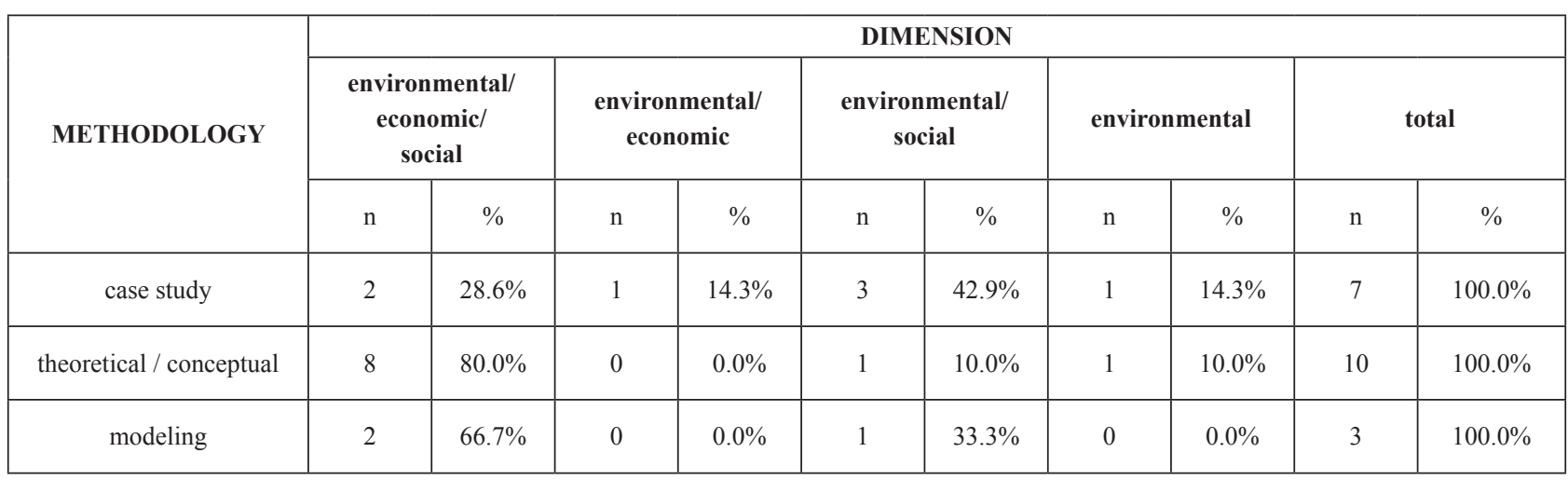

Table 7. Scales covered versus dimensions of sustainability

\begin{tabular}{|c|c|c|c|c|c|c|c|c|c|c|}
\hline \multirow{3}{*}{ SCALE } & \multicolumn{10}{|c|}{ DIMENSION } \\
\hline & \multicolumn{2}{|c|}{$\begin{array}{c}\text { environmental/ } \\
\text { economic/ } \\
\text { social }\end{array}$} & \multicolumn{2}{|c|}{$\begin{array}{l}\text { environmental/ } \\
\text { economic }\end{array}$} & \multicolumn{2}{|c|}{$\begin{array}{c}\text { environmental/ } \\
\text { social }\end{array}$} & \multicolumn{2}{|c|}{ environmental } & \multicolumn{2}{|c|}{ total } \\
\hline & $\mathrm{n}$ & $\%$ & $\mathrm{n}$ & $\%$ & $\mathrm{n}$ & $\%$ & $\mathrm{n}$ & $\%$ & $\mathrm{n}$ & $\%$ \\
\hline global & 9 & $64.3 \%$ & 1 & $7.1 \%$ & 3 & $21.4 \%$ & 1 & $7.1 \%$ & 14 & $100.0 \%$ \\
\hline
\end{tabular}

Table 8. Approach versus dimensions of sustainability

\begin{tabular}{|c|c|c|c|c|c|c|c|c|c|c|}
\hline \multirow{3}{*}{ APPROACH } & \multicolumn{10}{|c|}{ DIMENSION } \\
\hline & \multicolumn{2}{|c|}{$\begin{array}{c}\text { environmental/ } \\
\text { economic/ } \\
\text { social } \\
\end{array}$} & \multicolumn{2}{|c|}{$\begin{array}{l}\text { environmental/ } \\
\text { economic }\end{array}$} & \multicolumn{2}{|c|}{$\begin{array}{l}\text { environmental/ } \\
\text { social }\end{array}$} & \multicolumn{2}{|c|}{ environmental } & \multicolumn{2}{|c|}{ total } \\
\hline & $\mathrm{n}$ & $\%$ & $\mathrm{n}$ & $\%$ & $\mathrm{n}$ & $\%$ & $\mathrm{n}$ & $\%$ & $\mathrm{n}$ & $\%$ \\
\hline critical theory & 8 & $57.1 \%$ & 1 & $7.1 \%$ & 3 & $21.4 \%$ & 2 & $14.3 \%$ & 14 & $100.0 \%$ \\
\hline resolution problems & 4 & $66.7 \%$ & 0 & $0.0 \%$ & 2 & $33.3 \%$ & 0 & $0.0 \%$ & 6 & $100.0 \%$ \\
\hline
\end{tabular}

Table 9. Journal versus dimensions of sustainability

\begin{tabular}{|c|c|c|c|c|c|c|c|c|c|c|}
\hline \multirow{3}{*}{ PERIODIC } & \multicolumn{10}{|c|}{ DIMENSION } \\
\hline & \multicolumn{2}{|c|}{$\begin{array}{c}\text { environmental/ } \\
\text { economic/ } \\
\text { social }\end{array}$} & \multicolumn{2}{|c|}{$\begin{array}{l}\text { environmental/ } \\
\text { economic }\end{array}$} & \multicolumn{2}{|c|}{$\begin{array}{l}\text { environmental/ } \\
\text { social }\end{array}$} & \multicolumn{2}{|c|}{ environmental } & \multicolumn{2}{|c|}{ total } \\
\hline & $\mathrm{n}$ & $\%$ & $\mathrm{n}$ & $\%$ & $\mathrm{n}$ & $\%$ & $\mathrm{n}$ & $\%$ & $\mathrm{n}$ & $\%$ \\
\hline Harvard Business Review & 0 & $0.0 \%$ & 1 & $100.0 \%$ & 0 & $0.0 \%$ & 0 & $0.0 \%$ & 1 & $100.0 \%$ \\
\hline Journal of Cleaner Production & 9 & $64.3 \%$ & 0 & $0.0 \%$ & 4 & $28.6 \%$ & 1 & $7.1 \%$ & 14 & $100.0 \%$ \\
\hline Chemical Engineering \& Tecnology & 1 & $100.0 \%$ & 0 & $0.0 \%$ & 0 & $0.0 \%$ & 0 & $0.0 \%$ & 1 & $100.0 \%$ \\
\hline Water Science and Technology & 0 & $0.0 \%$ & 0 & $0.0 \%$ & 0 & $0.0 \%$ & 1 & $100.0 \%$ & 1 & $100.0 \%$ \\
\hline Futures & 1 & $100.0 \%$ & 0 & $0.0 \%$ & 0 & $0.0 \%$ & 0 & $0.0 \%$ & 1 & $100.0 \%$ \\
\hline $\begin{array}{c}\text { International Journal of Higher } \\
\text { Education in Sustainability }\end{array}$ & 1 & $50.0 \%$ & 0 & $0.0 \%$ & 1 & $50.0 \%$ & 0 & $0.0 \%$ & 2 & $100.0 \%$ \\
\hline
\end{tabular}


Table 10. Year versus dimensions of sustainability

\begin{tabular}{|c|c|c|c|c|c|c|c|c|c|c|}
\hline \multirow{3}{*}{ YEAR } & \multicolumn{10}{|c|}{ DIMENSION } \\
\hline & \multicolumn{2}{|c|}{$\begin{array}{c}\text { environmental/ } \\
\text { economic/ } \\
\text { social }\end{array}$} & \multicolumn{2}{|c|}{$\begin{array}{l}\text { environmental/ } \\
\text { economic }\end{array}$} & \multicolumn{2}{|c|}{$\begin{array}{l}\text { environmental/ } \\
\text { social }\end{array}$} & \multicolumn{2}{|c|}{ environmental } & \multicolumn{2}{|c|}{ total } \\
\hline & $\mathrm{n}$ & $\%$ & $\mathrm{n}$ & $\%$ & $\mathrm{n}$ & $\%$ & $\mathrm{n}$ & $\%$ & $\mathrm{n}$ & $\%$ \\
\hline 1997 & 0 & $0.0 \%$ & 1 & $100.0 \%$ & 0 & $0.0 \%$ & 0 & $0.0 \%$ & 1 & $100.0 \%$ \\
\hline 1998 & 1 & $50.0 \%$ & 0 & $0.0 \%$ & 0 & $0.0 \%$ & 1 & $50.0 \%$ & 2 & $100.0 \%$ \\
\hline 2006 & 2 & $50.0 \%$ & 0 & $0.0 \%$ & 2 & $50.0 \%$ & 0 & $0.0 \%$ & 4 & $100.0 \%$ \\
\hline 2008 & 1 & $100.0 \%$ & 0 & $0.0 \%$ & 0 & $0.0 \%$ & 0 & $0.0 \%$ & 1 & $100.0 \%$ \\
\hline 2010 & 2 & $100.0 \%$ & 0 & $0.0 \%$ & 0 & $0.0 \%$ & 0 & $0.0 \%$ & 2 & $100.0 \%$ \\
\hline 2011 & 0 & $0.0 \%$ & 0 & $0.0 \%$ & 1 & $100.0 \%$ & 0 & $0.0 \%$ & 1 & $100.0 \%$ \\
\hline 2012 & 1 & $33.3 \%$ & 0 & $0.0 \%$ & 2 & $66.7 \%$ & 0 & $0.0 \%$ & 3 & $100.0 \%$ \\
\hline 2013 & 5 & $100.0 \%$ & 0 & $0.0 \%$ & 0 & $0.0 \%$ & 0 & $0.0 \%$ & 5 & $100.0 \%$ \\
\hline 2015 & 0 & $0.0 \%$ & 0 & $0.0 \%$ & 0 & $0.0 \%$ & 1 & $100.0 \%$ & 1 & $100.0 \%$ \\
\hline
\end{tabular}

sustainability and HEI, given the fact that research in this area is a global trend at present, due to the absence of reference articles in recent years. Still, this research presents a broad reading of the literature and finds trends consistently reported by others.

It recognizes as a limitation. This study has only exploratory and involves subjectivity in the interpretation of articles of the selected sample. Thus, new future research on the subject of this research should be conducted in order to clarify and closer and closer to the themes explored.

Despite efforts to systematically collect a solid set of studies, there are limitations to this research. First, the study was limited to journal articles found by the selected database. Second, the content analysis is based on the results reported by other authors, and there is little room to control the quality and integrity of the results of others as well as the selective biases of the authors.

However, the number of confirmed discussions to consider the dimensions of sustainability fully and effectively in the HEI, with models and methods applicable in different natures, is a major legal challenge to advance the frontiers of knowledge, may be a relevant topic for future research.

\section{Author Contributions}

Both authors conceived the idea. Erika Bedin collected and analyzed the data and prepared the first version. Luiz Faria supervised the planning and execution of the activities. Both discussed the results and contributed to the final version of the manuscript.

\section{Conflict of Interest}

The authors declare that there is no conflict of interest.

\section{References}

[1] Sachs, I, 1986. Ecodevelopment: grow without de- stroying. Vértice, São Paulo.

[2] Sachs, I, 1993. Transition strategies for the 21st century: development and environment. Studio Nobel/ Fundap, São Paulo.

[3] Maimon, D, 1992. Company and Environment. Time and Presence. Tempo e Presença, 14, 261, 49-51.

[4] Maimon, D, 1994. Eco-strategy in Brazilian companies: reality or discourse? Journal of Business Administration, 34, 4, 119-130. https://doi.org/10.1590/ S0034-75901994000400013.

[5] Maimon, D, 1996. Green Passport: environmental management and competitiveness. Qualitymark, Rio de Janeiro.

[6] Donaire, D, 1994. Considerations on the influence of the environmental variable on the firm. Journal of Business Administration, 34, 2, 68-77. https://doi. org/10.1590/S0034-75901994000200008.

[7] Barbieri, JC, 2001. Development and Environment: Agenda 21's Strategies for Change. Vozes, Petrópolis.

[8] Berté, R, 2009. Social and Environmental Management in Brazil. Saraiva, São Paulo.

[9] Arvidsson, K, 2004. Environmental management at Swedish universities. International Journal of Sustainability in Higher Education, Hamburg, 5, 1, 9199. https://doi.org/10.1108/14676370410512616.

[10] Noeke, J, 2000. Environmental management systems for universities: A case study. International Journal of Sustainability in Higher Education, 1, 3, 237-251. https://doi.org/10.1108/14676370010378167.

[11] Herremans, I; Allwright, DE, 2000. Environmental management systems at North American universities: What drives good performance? International Journal of Sustainability in Higher Education. Hamburg, 1, 2, 168-181. https://doi.org/ 10.1108/1467630010371902.

[12] Carpenter, D; Meehan, B, 2002. Mainstreaming en- 
vironmental management: case studies from Australasian universities. International Journal of Sustainability in Higher Education, 3, 1, 19-37. https://doi. org/10.1108/14676370210414155.

[13] Sammalisto, K Arvidsson, K, 2005. Environmental management in Swedish higher education Directives, driving forces, hindrances, environmental aspects and environmental co-ordinators in Swedish universities. International Journal of Sustainability in Higher Education, 6, 1, 18-35. https://doi. org $/ 10.1108 / 14676370510573113$.

[14] Ashby, A, Leat, M, Hudson-Smith, M, 2012. Making connections: a review of supply chain management and sustainability literature. Supply Chain Management: an international journal, 17, 5, 497-516. https:// doi.org/10.1108/13598541211258573.

[15] Bufrem, L; Prates, Y, 2005. Registered scientific knowledge and information measurement practices. Information Science, Brasília, 34, 2, 9-25. https://doi. org/10.1590/S0100-19652005000200002.

[16] Hart, SL, 1997. Beyond greening: Strategies for a sustainable world. Harvard Business Review, 75, 1, 66, 1997.

[17] Uhl, C., D. Kulakowski, J. Gerwing, M. Brown and M. Cochrane. 1996. Sustainability: A touchstone concept for university operations, education, and research. Conservation Biology 10(1308): 1311.
[18] Lozano, R, 2006. Incorporation and institutionalization of SD into universities: breaking through barriers to change. Journal of Cleaner Production, 14, 9-11, 787-796. https://doi.org/10.1016/j.jclepro.2005.12.010.

[19] Alshuwaikhat, HM, Abubakar, I, 2008. An integrated approach to achieving campus sustainability: assessment of the current campus environmental management practices. Journal of Cleaner Production, 16, 6, 1777-1785. https://doi.org/10.1016/j.jclepro.2007.12.002.

[20] Daub, CH, 2007. Assessing the quality of sustainability reporting: an alternative methodological approach. Journal of Cleaner Production, 15, 1, 75-85. https://doi.org/10.1016/j.jclepro.2005.08.013.

[21] Lozano, R; Lukman, R; Lozano, FJ; Huisingh, D; Lambrechts, W, 2013. Declarations for sustainability in higher education: becoming better leaders, through addressing the university system. Journal of Cleaner Production, 48, 1, 10-19. https://doi.org/10.1016/j.jclepro.2011.10.006.

[22] Lozano, R, 2010. Diffusion of sustainable development in universities' curricula: an empirical example from Cardiff University. Journal of Cleaner Production, 18, 7, 637-644. https://doi.org/10.1016/j.jclepro.2009.07.005. 